\title{
The Effect of Load on The Back to Physiological Response of Heaver in Pasar Legi Surakarta
}

\author{
Suprapto \\ Universitas Veteran Bangun Nusantara \\ Sukoharjo, Indonesia \\ supraptodd@yahoo.co.id
}

\author{
Ainur Komariah \\ Universitas Veteran Bangun Nusantara \\ Sukoharjo, Indonesia \\ ainurkomariah@yahoo.com
}

\begin{abstract}
The goal of the research knows the effect of load which is carry on the back to physiological response of heaver in Pasar Legi Surakarta. Research subjects are 15 female heavers, 20-25 years old, height around $140-160 \mathrm{~cm}$, weight around 40-60 $\mathrm{kg}$, and don't have hypertension and rheumatism. The varieties of load are $50 \mathrm{~kg}, 75 \mathrm{~kg}$, and 100 kg. Measurement of the load by measuring the pulse with pulse meter. The result of normality and homogeneity test of pulse differences (P0-P1) shows that samples are normal and have the same variance. The result of the analysis of average pulse variances in three loading treatments obtains a significance value of $p<0,05$, which means there is a significant effect of loading treatments on physiological response. Furthermore, post hoc analysis of three different treatments obtain $p<0,05$ and it can be concluded there significant difference among three different loading treatment on physiological response. Compare to load of 50 $\mathrm{kg}$ and $75 \mathrm{~kg}$, the load of $100 \mathrm{~kg}$ has the potential risk to cause injury to the physiological of heavers in Pasar Legi Surakarta.
\end{abstract}

Keywords: Heaver, Pasar Legi, Physiological

\section{INTRODUCTION}

The job as a heaver who carry the load on the back is one characteristic of female heavers in Pasar Legi Surakarta. This job is one of opportunity to people who not work in formal occupation, this job has no require of particular skill and particular education.

The activity of carrying loading on the back has potential risk of injury. The effect of carry loading cause musculoskeletal pain on body segment especially on the part which is direct contact with the loading [1]. The activity of carrying loading in continued has potential risk of injury and the maksimum loading that are allowed of comtinued carrying is $25 \mathrm{~kg}$. On manual carrying of loading more tham maksimum loading limit cause injury on low back pain which is cramps. [2]. Manual carrying which is not carry on ergonomic way cause the injury on work [3]. The accident on work called "over exertionlifting and carrying" is breakdown of body tissue caused by excess loading lifting [4]. The accident on work cause by continued activity, shape, and size of tool that used on work [5]. [2] find the significant pain on the back of the worker who work on job more than the maximum strength of muscle [6]. [7] shows the majority of operators on port loading and unloading worker suffer from pain on skeletal muscles which is low back pain, right and left shoulders, left upper arm, right calf and left toes.
Related to human work ergonomics studies has the goal to evaluate dan design ways of working that can be applied to increase effectiveness and efficiency, in addition the comfort and safety of human as workers. Energy which is used on working activity obtained by metabolism, respiration, and circulation [8]. [9] states the loading of lifting effect on energy expenditure for tenongan food seller. The loading of $10 \mathrm{~kg}, 15 \mathrm{~kg}$, dan 20 $\mathrm{kg}$ with the distance of every loading release energy 4.91 $\mathrm{kkal}, 5.87 \mathrm{kkal}$ dan $6.51 \mathrm{kkal}$. The energy consumption is not enough to estimate the physical working, but it determined by amount of the muscles that participate and static loading and also level of heat preasure and the place of working that can increase the pulse [10]. To estimate the loading level use heart rate recovery [10]. [11] do research on comparing lifting loading on the back on three different treatment, first one on the upper side of back, second the middle side of back, and the third is the low side of the back. From the research concludes loading on three different side (upper, middle or lower) indicates different oxygen consumption, pulse, and level of energy using. Participant on the research said that carry the loading on the upper side of the back is more difficult than the lower side.

Generally the problem on activity is the pain after carrying loading. It caused by the loading are not equal with the energy consumption. This phenomenon must be analyzed on the effect of load on the back which is carried by the heavers to their physiological response, thus level of fatigue and muscle injury can be minimized.

\section{METHODS}

\section{A. Research Subject}

The 15 female heaver, 20-25 years old, height around $140-160 \mathrm{~cm}$, weight around $40-70 \mathrm{~kg}$. They don't have hypertension and rheumatism.

\section{B. Research Object}

Three loadings are $50 \mathrm{~kg}, 75 \mathrm{~kg}$, and $100 \mathrm{~kg}$, loading is put on the back tied by shawl, the range is $100 \mathrm{~m}$ and the measuring of pulse are before and after the loading treatments.

\section{Research Tool}

Pulse meter to measuring the pulse and measuring scales maksimum $150 \mathrm{~kg}$ 


\section{Measure Pulse Procedure}

The procedure of measure of workload with the pulse:

1. Prepare the tools and loadings for research.

2. Deliver the foreword about the goal of the research, give the explanation of the ways of working to research subject.

3. Research subjects do the loading treatments, they bring one by one of loading which are $50 \mathrm{~kg}, 75 \mathrm{~kg}$, $100 \mathrm{~kg}$ tied on shawl.

4. Before the subject do the loading treatment, their pulse are measure use pulse meter as basic measurement (P0).

5. After they do the loading treatments, their pulse are measured for each different loading after 30 second of loading treatment.

6. The frequency of loading treatments for research subject is one times for each loading of $50 \mathrm{~kg}, 75 \mathrm{~kg}$, and $100 \mathrm{~kg}$.

\section{E. Hypothesis}

Hypothesis testing the different effect of loading treatment with a significant level of $\alpha=0.05$.

1. Test for Normality and Homogeneity of Variances

Normality test

Using the Kolmogorov-Smirnov (K-S) test to determine whether the sample comes from a population that has a theoretical distribution.

a. Formulations $\mathrm{H}_{0}$ and $\mathrm{H}_{1}$

$\mathrm{H}_{0}$ : a sample of a population that is normally distributed.

$\mathrm{H}_{1}$ : a sample of a population that is not normally distributed.

b. b. Decision

$\mathrm{H}_{0}$ is accepted if $\mathrm{p}>0.05$ means a sample from a nomal population.

$\mathrm{H}_{0}$ is rejected if $\mathrm{p}<0.05$ means that the sample is not from the nomal population.

Homogeneity Variance Test

To find out whether the measurement of workload based on pulse has the same variance.

a. Formulations $\mathrm{H}_{0}$ and $\mathrm{H}_{1}$

$\mathrm{H}_{0}$ : The variance of each path is homogeneous.

H1: The variance of each path is not homogeneous

b. Decision

$\mathrm{H}_{0}$ is accepted if $\mathrm{p}>0.05$ means that the variance of each path is homogeneous.

$\mathrm{H}_{0}$ is rejected if $\mathrm{p}<0.05$ means that the variance of each path is not homogeneous.

2. Test of Difference in Pulse Rate

\begin{tabular}{lccccc}
\multicolumn{6}{c}{ Table 1. The Measurement Result of Anova Differences Pulse $\left(\mathrm{P}_{0}-\mathrm{P}_{1}\right)$} \\
\hline & $\begin{array}{c}\text { Sum of } \\
\text { Squares }\end{array}$ & $\mathrm{df}$ & $\begin{array}{c}\text { Mean } \\
\text { Square }\end{array}$ & $\mathrm{F}$ & Sig. $(\mathrm{p})$ \\
\hline Between & 2867.51 & 2 & 1433.755 & 17.76 & \\
Groups & 1 & 2 & & 8 & 0.000 \\
Within & 3389.06 & 4 & 80.693 & & \\
Groups & 7 & 2 & & & \\
Total & 6258.57 & 4 & & & \\
& 8 & 4 & & &
\end{tabular}

Post Hoc Test is the differencea between average pulse for every loading has the significant result which are 0,$003 ; 0,000$; and 0,009 or $p<0,05$, ther conclusion is $\mathrm{H}_{0}$ a. Formulations $\mathrm{H}_{0}$ and $\mathrm{H}_{1}$

$\mathrm{H}_{0}: \mu 1=\mu 2=\mu 3$ (There is no difference in the effect of the load on the back at each load of $50 \mathrm{~kg}, 75 \mathrm{~kg}, 100 \mathrm{~kg}$ on physiological response).

$\mathrm{H}_{1}$ : There are one or more of different $\mu$ s (There are differences in the influence of the load on the back on each load of $50 \mathrm{~kg}, 75 \mathrm{~kg}, 100 \mathrm{~kg}$ on physiological response).

\section{b. Decision}

$\mathrm{H}_{0}$ is accepted if $\mathrm{p}>0.05$ means that there is no significant difference between the average load on the back and the physiological response.

$\mathrm{H}_{0}$ is rejected if $\mathrm{p}<0.05$ means there is a significant difference between the average load on the back and the physiological response.

\section{THE RESULT}

\section{A. Average Pulse}

In a day the heavers carry the loading 10 times or more use shawl to carry the loading from truck to the store or reach the buyers. The heavers are ready on market at 04.00 a.m. before the supplier truck come. The result of pulse average measurement and the differences of the heaver's pulse in Pasar Legi Surakarta before and after the loading treatment shows on Table 1.

\begin{tabular}{llll}
\multicolumn{4}{l}{ Table 2. Average and Differences of The Pulse } \\
\hline Loading & $\mathrm{P}_{0}$ & $\mathrm{P}_{1}$ & $\mathbf{P}_{\mathbf{1}}-$ \\
& & & $\mathbf{P}_{\mathbf{0}}$ \\
\hline $50 \mathrm{~kg}$ & 90,00 & 100,13 & 10,13 \\
$75 \mathrm{~kg}$ & 90,00 & 110,67 & 20,67 \\
$100 \mathrm{~kg}$ & 90,00 & 116,67 & 26,67 \\
\hline
\end{tabular}

\section{B. Pulse Rate Workload}

The results of normality testing using KolmogorovSmirnov from the treatment of $50 \mathrm{~kg}, 75 \mathrm{~kg}$ and $100 \mathrm{~kg}$ loads with a significant level of 0.05 obtained $\mathrm{p}$ value of 0.328 respectively; $0.913 ; 0.855$ or overall $p>0.05$ then $\mathrm{H}_{\mathbf{0}}$ is accepted so that it can be concluded that the sample is from a normal population. The test results of homogeneity of variance with a significant level of 0.05 obtained $p$ value of 0.327 or $p>0.05$ then $\mathrm{H}_{0}$ was accepted so that it can be concluded that the data from the three loading treatment groups had the same (homogeneous) variance and $\mathrm{H}_{1}$ accepted, the conclusion is the average pulse of loading treatments which the loading are $50 \mathrm{~kg}$, $75 \mathrm{~kg}$, and $100 \mathrm{~kg}$ has significant differences. Therefore there is effect pn loading treatment on the back against physiological response of the heavers in Pasar Legi Surakarta.

rejected and $\mathrm{H}_{1}$ accepted. Thus, the differences of average pulse is significant. The change from loading $50 \mathrm{~kg}$ to loading of $100 \mathrm{~kg}$ has the average different 19,533 more tham the change from loading to $50 \mathrm{~kg}$ to $75 \mathrm{~kg}$ or $75 \mathrm{~kg}$ to $100 \mathrm{~kg}$. Therefore the activity of carrying load on the back which the loading is $100 \mathrm{~kg}$ has the potential risk of injury on physiological response of heavers in Pasar Legi Surakarta. 
Table 3. Post Hoc Measurement of The Differences of The Pulse $\left(\mathrm{P}_{0}\right.$ $\left.\mathrm{P}_{1}\right)$

\begin{tabular}{llcc}
\hline Treatment (I) & Treatment (J) & $\begin{array}{l}\text { Differences of } \\
\text { Treatment (I-J) }\end{array}$ & Sig.(p) \\
\hline $50 \mathrm{~kg}$ & $75 \mathrm{~kg}$ & $-10,533$ & 0,003 \\
$50 \mathrm{~kg}$ & $100 \mathrm{~kg}$ & $-19,533$ & 0,000 \\
$75 \mathrm{~kg}$ & $100 \mathrm{~kg}$ & $-9,000$ & 0,009 \\
\hline
\end{tabular}

\section{CONCLUSION}

Based on the discussion we can conclude that the bigger loading effect the pulse. The loading treatment on the back give significant effect on physiological response. Activity of carrying load on the back has potential risk for heaver in Pasar Legi Surakarta, because this activity has direct contact between loading and back. Heavy loading on the muscles or skeletel system cause muscle overstain, especially muscles that has direct contact with the loading. Big and continued physiological loading will give disadvantages to the health and safety of the workers.

\section{ACKNOWLEDGMENT}

This research was supported by managemet of Paguyuban Kuli Gendong in Pasar Legi Surakarta.

\section{REFERENCES}

[1] Suprapto dan Wibowo, B. Pengaruh Beban Angkat Ditinjau Dari Aspek Fisiologis Dan Muskuloskeletal Para Pedagang Asongan di Terminal Bus "Tirtonadi" Surakarta, Laporan Penelitian Dosen Muda, DP2M Direktorat Jenderal Pendidikan Tinggi Departemen Pendidikan Nasional. 2008.
[2] Chaffin , D.B., dan Anderson, G.B.J, Occupational Biomechanics. $2^{\text {nd }}$. Edition Toronto Canada, John Wiley \& Sons Inc. 1991.

[3] Purnomo, H. Konsep Mekanika Untuk Menganalisis Gaya dan Momen Pada Sistem Kerangka Otot. TEKNOIN Vol. 5. No. 2 hal 115127. 2000.

[4] Rodgers, S.H, Ergonomic Design for People at Work, New York: Van Nostrand Reinhold Co. 1986.

[5] Kroemer KHE.1994. Ergonomics: How to Design for Ease and Efficiency. Prentice Hall International Inc.

[6] Watters, T.S dan Anderson, Revise NIOSH Lifting Equation, In : Bharattacharya A. and McGlothlin. J.D. Editor. Occupational Ergonomics Theory and Application. New York : Marcel Dekker Inc. 1996.

[7] Sudiajeng, I., Tarwaka, Hadi, S, Ergonomic Evaluation of Lifting and Carrying in Tradisional Pouring Concrete Slab for Multilevel Building. Dalam: Sutajaya, M. Editor. National-International seminar on Ergonomic Sport-physiology. Denpasar : Udayana University Press. 2001 .

[8] Elgin, M., Coles, C., and Tipton, J., 2004, Physilogical Responses of Fire-Figter Instructors During Training Exercises. Journal of Ergonomics, Taylor and Francis Ltd. Vol. 47. No.5 p. 483-494.

[9] Oesman. T.I. 2004., Analisis Berat Beban Penjual Makanan Keliling (Tenongan) Ditinjau dari Aspek Biomekanika. Proceeding Seminar Nasional Ergonomi 2. Yogyakarta. FTP UGM.

[10] Grandjean. E. 1986. Fitting The Task To The Man. London : Taylor \& Francis

[11] Tayyari. F, dan Smith. J. 1997. Occupational Ergonomic Principle and Application. London: Champman \& Hall.

[12] Stuempfle, K.J., Drury, D.G. and Wilson, A.L. 2004. Effect of Load Position on Physiological and Perceptual Responses During Load Carriage With and Internal Frame Backpack. Journal of Ergonomics. Taylor and Francis Ltd. Vol. 47. No. 7 p. 784-789. 